Colman, A. M. (1983). Attitudes of British police officers: A rejoinder. Sociology, 17, 388-391.

\title{
ATTITUDES OF BRITISH POLICE OFFICERS: A REJOINDER
}

\section{ANDREW M. COLMAN}

Biographical Note: ANDREW M. COLMAN, Ph.D., is a lecturer in the Department of Psychology, The University, Leicester LE1 7RH. He is the author of What is Psychology? (London: Kogan Page, 1981) and Game Theory and Experimental Games: The Study of Strategic Interaction (Oxford: Pergamon, 1982), co-author of Introducing Psychology (Harmondsworth: Penguin, 1982), and editor of Cooperation and Competition in Humans and Animals (Wokingham: Van Nostrand Reinhold, 1982). 


\begin{abstract}
Waddington's comment on 'Conservatism, Dogmatism, and Authoritarianism in British Police Officers' by Colman and Gorman is motivated, in part at least, by overtly political considerations. None of his specific criticisms bears close scrutiny. One is based on a selective misquotation which conveys the opposite meaning to that of the original; a second focuses on a supposed 'lack of illiberalism' among police officers which is clearly contradicted by the data, and a third arises from an elementary blunder in the interpretation of a statistically nonsignificant difference.
\end{abstract}

WADDINGTON $^{1}$ has attacked a recent paper by myself and Paul Gorman ${ }^{2}$ on British police officers' attitudes, for reasons that, in part at least, are overtly political. He believes that our findings (he places 'findings' in sneer quotes) give a 'false and damaging impression of police officers' attitudes, 3 and that sociologists have a duty 'to prevent saying anything which unjustifiably might further exacerbate the current crisis in police-community relations, ${ }^{4}$. Some would no doubt argue, on the contrary, that the censorship or self-censorship of research findings on political grounds advocated by Waddington might further exacerbate the current crisis in sociology, since academic disciplines thrive on the free flow of ideas. In any event, by bringing the extent of anti-Black prejudice among the police out into the open, our research was partly responsible for a recommendation in the Scarman Report that was designed to improve policecommunity relations. ${ }^{5}$

Waddington's article is peppered with misquotations and distortions. He claims, firstly, that one of our three conclusions was "that "socialization into the police subculture leads to an increase in conservatism, dogmatism, and authoritarianism”“6 and he goes on to say that we were 'simply wrong' to reach this conclusion because the differences between recruits' and probationers' scores on the relevant scales were small and non-significant, and in the case of dogmatism, in the wrong direction. ${ }^{7}$ But as Waddington must know, what we actually said was this: 'The statistical analyses of the psychometric test scores lend no support to the view that socialization into the police subculture leads to an increase in conservatism, dogmatism, and authoritarianism' ${ }^{8}$ This is the exact opposite of what Waddington, by omitting the italicized words from the quotation, makes us appear to have said! His criticism is therefore not only unjustified, but also irresponsible and calculated to mislead. He goes on to assert that our explanation for this and other findings was 'that the police service recruits those who, being of lower educational attainment than those in occupations of comparable socoi-economic level, are more likely to possess illiberal and intolerant attitudes'. ${ }^{9}$ But we said quite emphatically that 'educational factors cannot, however, account for the differences found within and between the police groups themselves'. ${ }^{10}$

There is a certain unintended irony in Waddington's allegation--for which he provides no scrap of evidence--that it is we who 'interpret [our] own data in a selective and distorting fashion, ${ }^{11}$ and that it is we who are 'so partial as to convey a distortion of the evidence'. ${ }^{12}$ The same might be said of his sententious plea for sociologists to 'defend standards of scholarship' ${ }^{13}$

We did conclude in our original paper 'that the police force tends to attract to it people who are more conservative and authoritarian than those of comparable socioeconomic status in other occupations'. ${ }^{14}$ This conclusion was based on the finding that the recruits, who were tested right at the start of their basic training, scored significantly higher on well-validated scales designed to 
measure conservatism and authoritarianism than did a control group of civilians, who were matched with the recruits on socioeconomic status. Waddington criticizes this conclusion on the grounds that it 'ignores the findings that the recruits were not significantly more illiberal and intolerant than the control group on the three controversial issues to which the authors elicited open-ended comments, namely capital punishment, coloured immigration, and mixed marriages' ${ }^{15}$ As explained in the original paper, these three items were selected from one of the conservatism scales, which contains 50 items in all, in order to assess illiberalism/intolerance on specific issues, not conservatism and authoritarianism in general. In all three cases the recruits' essays were rated as more illiberal/intolerant, on average, than those of the civilian controls, but none of these differences reached statistical significance and therefore no conclusions were inferred from them. None the less, the recruits' scores on the conservatism scale as a whole were significantly higher, as were their scores on the authoritarianism scale, and our conclusion was therefore perfectly correct. It is worth pointing out, furthermore, that the recruits' open-ended essays on the three specific issues certainly did not show 'a lack of illiberalism on these issues' as Waddington claims. ${ }^{16}$ On the contrary, they showed a disturbing degree of illiberalism and intolerance.

On the measure of dogmatism used in our study, the recruits, probationers, and civilians did not differ significantly. Waddington nevertheless asserts in italics that 'the probationers were the least dogmatic of the three groups' ${ }^{17}$ He refers to this as a 'fact' and accuses us of ignoring it for ideological reasons. This allegation is based on a simple misunderstanding of the logic of statistical hypothesis testing. No firm conclusions, and a fortiori no 'facts', about group differences can ever be inferred from a statistically non-significant average difference, as any elementary statistical text will confirm. I am firmly of the opinion that those who presume to place their writings before the public have a duty to strive for accuracy and fairness, above all when they are discussing research findings that they find uncongenial. The research that Waddington attacks was planned, conducted, and presented with the greatest care and circumspection, and although it probably contains flaws in spite of our efforts, Waddington's paper will not help anyone to find them. It would be tedious and pointless to mention all of the errors, distortions, and misunderstandings in Waddington's article: I have counted 14 errors ${ }^{18}$ (some trivial, some more significant) on the first page alone.

Notes

1. P. A. J. Waddington, ““Conservatism, Dogmatism, and Authoritarianism in British Police Officers”: A Comment’, Sociology, 1982, vol. 16, pp. 591-4.

2. A. M. Colman and L. P. Gorman, 'Conservatism, Dogmatism, and Authoritarianism in British Police Officers’, Sociology, 1982, vol. 16, pp. 1-11.

3. Waddington, op. cit., p. 591, Abstract.

4. Ibid., p. 593. Whom does he want to 'prevent'? One hopes that he merely means 'avoid'.

5. The Brixton Disorders 10-12 April 1981: Report of an Inquiry by the Rt. Hon. the Lord Scarman, O.B.E., London: Her Majestey’s Stationery Office, 1981. On p. 79 Scarman quotes our paper in support of his recommendation for screening police recruits in an effort to identify racial prejudice. 
6. Waddington, op. cit., p. 591. This wilful misquotation (see following text), and the assertion that it is 'simply wrong', are repeated on p. 592.

7. Ibid., p. 592. The differences were not as small as Waddington implies. On the Social and Political Attitude Inventory (one of our measures of conservatism), for example, the average score of the recruits was 81.00 and that of the probationers was 85.42; this is a difference of more than half a standard deviation--a difference of 4.42 scale points (these figures appear in Table 1 in our original article). Compare this with the 'one scale point' difference selected from the table by Waddington and described by him on p. 592 of his article as 'the extent of this tendency'.

8. Colman and Gorman, op. cit., pp. 8-9. Italics added.

9. Waddington, op. cit., p. 591.

10. Colman and Gorman, op. cit., p. 10. Italics added. The difference at issue here is between recruit and probationer police officers.

11. Waddington, op. cit., p. 591, Abstract.

12. Ibid., p. 591.

13. Ibid., p. 593.

14. Colman and Gorman, op. cit., p. 8. Waddington's paraphrase of this finding, which occurs twice on p. 591 of his article, is strictly meaningless. His version says merely that 'the police service recruits those with more conservative and authoritarian attitudes' without specifying any comparison group. This conveys about as much sense as 'plumbers earn more money' or 'Daz washes whiter'.

15. Waddington, op. cit., p. 591. Actually, the first was 'death penalty', not 'capital punishment'. Attitudes towards these two issues are not necessarily identical--a person may, for example, favour the death penalty as a deterrent, but none the less believe that it serves no useful purpose as a punishment. The third was 'mixed marriage' in general, not particular 'mixed marriages'.

16. Ibid., p. 592. The figures, given in the original paper, are as follows. On a five-point scale from 1 (liberal/tolerant) to 5 (illiberal/intolerant), the recruits' average scores were 3.49 (death penalty), 3.05 (coloured immigration), and 2.42 (mixed marriage). All of these averages are well above 1.00, the score that would indicate 'a lack of illiberalism on these issues'.

17. Ibid., p. 593. On p. 592 Waddington makes the same mistake (twice) by asserting that 'in fact, probationers were actually less dogmatic than recruits and were even less dogmatic than the control group'.

18. (i) Abstract, 1. 1: A comma is missing from the quoted title of our article. (ii) Abstract, ll. 3-4: Here, 'ethnic minorities' should read 'coloured immigration'. One could oppose coloured immigration (in the belief, say, that it causes social problems) without being personally hostile to any ethnic minorities. (iii) Text, l. 2: 'social attitudes' should read 'social attitudes, cognitive styles, and personalities'--see the prefatory remarks of our original article. (iv) Text, l. 3: The word 'precision' is incorrect in this context. Increased precision comes from more accurate 
measurement, whereas the purpose of the control group is to enable comparisons to be drawn. (v) Text, 1. 4: 'These data' should (presumably) read 'their data', since it is conclusions from our own data that are allegedly unrigorous. (vi) Text, l. 5: 'The police service recruits' should read 'the police service tends to recruit'; the trend is only statistical, with many exceptions, as we pointed out. (vii) Text, ll. 5-6: This formulation is nonsensical, and it is not ours--see Note 14. (viii) Text, ll. 7-8: The third 'finding' was no such thing: it was not supported by our findings. (ix) Text, ll. 9-12: 'Their explanation for these findings' applies only to the first of the three findings mentioned; the other findings, which are based on comparisons within and between the police groups only, cannot be explained in this way, as emphasized on p. 10 of our originnal article. (x) Text, l. 20: There were no significant findings on dogmatism, so there was nothing here for us to ignore. (xi) Text, l. 20: 'Dogmatism among police officers' should read 'differences in dogmatism between probationers, recruits, and civilians', as becomes clear on p. 592, ll. 6-7 of Waddington's article. (xii) Text, ll. 23-4: The error referred to in (vii) is repeated here. (xiii) Text, l. 27: 'Capital punishment' should read 'death penalty'--see Note 15. (xiv) Text, 1.27: 'Mixed marriages’ should read ‘mixed marriage’--see Note 15. 